\title{
THE CONFESSIONS OF A CANADIAN OPUS EATER
}

It is considered bad form to explain a joke, and I suppose if one has to explain a title then it is an affectation to use it at all. Perhaps titles don't have to make sense, as long as they capture attention and arouse curiosity; but history-minded persons will not want to create a legacy of unravelled conundrums, causing posterity to scratch its head. I therefore suggest to you, having myself examined bibliographically thousands of Canadian titles during a period of twenty years, that the bibliographer in this long and voracious process might quite aptly be described as a 'Canadian Opus Eater'. Moreover, the act of setting forth one title after another, of examining opus after opus, gradually takes on the effect of an opiate; and in reflecting on a name for this paper, the title of the best-known work of Thomas De Quincey (1785-1859) sprang to mind as seeming to express, when slightly twisted, a parallel experience. His Confessions of an English OpiumEater (1821) laid the dreamy foundations for the life-style of some of our modern youth, and provides me with one of those literary allusions which are so popular with after-dinner speakers.

Perhaps all this may be regarded as my first 'confession'. Another is that I shall avoid discussing the unfolding of bibliographical mysteries because, although fascinating to encounter and resolve, they make very tedious listening.

The field which has interested me for the longest period of time is that of Canadian local histories, and it is gratifying that the subject has now become so popular. The result of this interest is a three-volume work entitled Canadian Local Histories to 1950: A Bibliography, the final volume of which is now being readied for the press. A quite separate work, covering the period subsequent to 1950 , is already being compiled by Ms. Barbara Aitken of Kingston, Ontario. Volume I of my work concerns the Atlantic Provinces; volume II, which was largely prepared by my esteemed collaborator M. André Beaulieu, covers the Province of Quebec; and the third volume embraces the local histories of Ontario and the Canadian North. The Prairie Provinces are already well covered by Mr. Bruce Peel (a former President of this society), in his celebrated Bibliography of the Prairie Provinces, and British Columbia local histories are included in the distinguished series of bibliographies of that province being published by the Social Sciences Research Centre of the University of Victoria since 1968. The three volumes for Eastern Canada and the Canadian North, taken together, have within them something approaching 3500 titles, and of course many more individual works than this if editions and issues are counted.

As my work progressed, more particularly on volumes I and III, I found it convenient to keep a file of titles which had already been examined and found to be inappropriate. In a project which extends over a span of many years, this 'Exclude' file is a valuable device for checking titles which have a familiar ring; 
it will save the duplicate handling of titles already rejected once, thus conserving the use of interlibrary loan facilities as well as the compiler's time. There were alarming periods though, when the 'Exclude' file seemed to be growing more rapidly than the bibliography itself; indeed, there are about 3000 cards in this file of excluded titles. If this number is extrapolated to embrace the Québec volume too, then about 5000 titles were examined and excluded, approximately the same number as were included. When editions, issues, and multiple volumes are added, then the figure is probably close to 15000 volumes examined. This is what I meari by 'opus eating'!

Mind you, the Checklist of Dr. R.E. Watters (a well known member of this Society) actually contains more titles than that: about 16,000; but that is a general work. 'Peel' is restricted to the three Prairie Provinces, and contains about 5000 titles; Dionne's Inventaire chronologique concerns only Quebec Province, and the five volumes comprise about 7000 monographs. To have gathered 5000 titles for six provinces and the Canadian North therefore, all restricted to local and regional history, gives some satisfaction, and is one more indication of the strong home-town attachments, the sectional loyalties, and the provincialism, which are so firmly embedded in the Canadian character.

One more statistical observation with which to bore you. In Canada most collections of printed local histories (and of Canadiana in general for that matter) are still relatively small, often regional in emphasis, and scattered over a wide geographical area coast to coast. The advantages of owning a private aeroplane are evident to every bibliographer! But such expensive conveniences, or even adequate travel funds, are rarely within his reach, so instead, he writes letters. My correspondence file for the three volumes contains about 5000 leaves of paper, of which about 3000 are carbon copies of letters from me, mostly pestering innocent people for bibliographical information. Imagine what havoc the creation of such an archive has wrought with my two typing fingers! It made me acutely aware of the need for more and quicker brown foxes with a lot fewer lazy dogs to jump over. But that's not all: if you add innumerable interlibrary loan forms, and also 'Request for Location' forms to the National Library for 3500 titles, you will readily see that bibliographers are 'paper eaters' as much as 'opus eaters'. Paper, in fact, is their staple diet, with a sprinkling of printer's ink and binder's glue for seasoning.

This tremendous amount of correspondence vividly illustrates a never-to-beforgotten aspect of bibliographical endeavour, and that is the bibliographer's great dependence upon the assistance of others: publishers, booksellers, librarians, archivists, private collectors, specialists in many different walks of life. There is an interesting paradox here. On the one hand the bibliographer works for days and years in solitary isolation, plodding away at his desk, with the social life of an anchorite and probably becoming a stranger even to his own family. Yet at the same time there are these strong lines of communication linking him or her at all times in the most amicable spirit of co-operation with others throughout the land - and often beyond. For this wonderful lifeline the bibliographer is ever indebted, and will always be especially grateful.

This strong dependency is made necessary by the bibliographer's need to examine personally, or at the very least indirectly, all works he describes. Such an examination is essential for accurately recognizing and distinguishing editions, 
issues, and variants ${ }^{1}$, and indeed for satisfying oneself that a particular work really does exist and is not a figment of someone's naiveté or carelessness what is imaginatively referred to as a 'ghost', as having no substantial existence.

Not always, however, is it possible to borrow a title required. For good and valid reasons it may be restricted by the owning library - though I have sometimes found that the list of bibliographical questions which must next be sent may cause the busy person responsible to bend the rules in your favour. Even less often is it possible to place a run of editions and issues side by side for a direct comparison, unless you are compiling the catalogue of a library. In order to bring all the pieces in a bibliographical jigsaw puzzle together, I have sometimes resorted to the device of a questionaire or circular letter. The purpose of this might be to survey all known copies of a work, to see if they were indeed copies, or whether perhaps a variant lurked amongst them; or it might be to untangle some anomaly in an earlier bibliographical description; but most often it will be to distinguish as precisely as possible the differences between editions and issues when the originals are non-circulating and scattered in many places.

I very soon learned that if a questionaire is to be effective it must be composed with great care, and from the viewpoint of the recipient who, after all, cannot read your mind. Otherwise, one bad questionaire leads to another. The questions should be as brief as clarity permits, and the vocabulary simple and precise, avoiding jargon: most people would, for example, look outside their houses for 'gutters', and at the ends of cheques and letters for 'signatures', not inside books. It is also best to leave spaces for replies right next to each query in the questionaire, so that the form itself will be returned to you, and with the title of the book, the question, and the answer and its source, all unseparated. Photocopies are inestimable aids to brevity, for as with pictures, one is worth a thousand words. Lastly, do leave space for additional remarks; I recall with profound gratitude the occasions when such remarks, appended perhaps as afterthoughts, opened a whole new line of investigation or flooded some obscure area with sudden light.

As is customary, I have attempted to provide full names and dates for personal author entries in the general index to the bibliography, using standard works of reference when these details could not be found within the local history itself. If these failed, I would write a letter only when there was a fairly obvious outside source. The replies, adding further to the correspondence files, were almost always useful, and sometimes amusing. The simple question: 'What were the full forenames and years of birth and death of such-and-such?' would occasionally bring back a fat letter detailing the family history going back for a hundred-andfifty years, enclosing perhaps genealogical tables and even faded photographs of ancestors. Sometimes these book-length letters included fervent appeals for information to fill out gaps in the family story. I formed a mental image of these dedicated people, always alert for any innocent bystander whom they might beguile into the glorious cause of their family history, and to whom so simple a question as 'In what year did your grandfather die?' is an open invitation. If, entombed within the contents of such letters, I found the answer to my questions,

${ }^{1}$ I use the guidelines laid down by Dr. Fredson Bowers, in his Principles of Bibliographical Description (Princeton, 1949), p. 39-42. 
then I would cheerfully search for reciprocal information; but the secret was to convey it in a tone which did not encourage further correspondence! No doubt it was the experience of such letters as these which persuaded me to adopt my present view: that genealogists are of all researchers the most devoted and persistent: qualities, it is appropriate to observe, which also serve bibliographers well.

This body of correspondence and documentation, which quietly and steadily accumulates over the years, becomes in itself a valuable resource for research in your subject field. The bibliographer, preoccupied with the immediate problems of the book he is attempting to describe, perhaps does not realize that as material on title after title is gathered, he or she is building a valuable and systematic archive. I reflect on the number of times I have corresponded with elderly persons, perhaps the last of their line, to gain first-hand information about the authorship of an anonymous or pseudonymous work, or an author's sources, or about the successive appearances of the text of a local history. In answer, a letter written by a trembling hand may be the only first-hand account in existance of the events surrounding a particular author and title. Such accounts ought to be preserved. Sometimes the facts I sought came back to me readily; but there were instances when the details were persistently elusive, and I found myself involved in many letters stretching over a long period, even running into years. On one occasion I was in correspondence with two persons each representing separate factions of a family which, I gradually became aware, were not only not speaking to each other but, it was becoming clear, actually held differing views of their illustrious relative; one who had done no more than write his own version of the hometown local history. In so doing, he had apparently become the unwitting contributor to family strife. The process of reconciling the two viewpoints, and of sifting fact from bias, began to take on the subtle complexities of a plot framed by the late Dame Agatha Christie. Indeed, the analogy is not so farfetched as it may appear, for bibliographical inquiry is, first and foremost, detective work. Occasionally, the trail leads outside Canada, most often to the United States, Britain and France, but also to less obvious places. I traced the grandson of one author to a town in Switzerland, and he was able to provide a wealth of background detail about both his grandparent and his book. (As an aside, one idly wonders what a small-town boy was doing in such an exotic retreat. Could he have retired there on the royalties from his grandfather's local history? In the immortal words of Eliza Doolittle, "Not bloody likely!")

To return to my point: the compilation of a bibliography, no less than investigations into other branches of knowledge, yields a quantity of specialized documentation. When the details resulting from each inquiry have been incorporated into your work, or rejected as inappropriate, this documentation then has no further immediate use for you. Some people may even regard the correspondence as worthless. Nothing could be farther from the truth. For one thing, you may not have transcribed all of the information available in your records; for another, these papers are your sources, the very evidence on which you have based certain published statements. You are not the authority here, this documentation is. I therefore exhort everyone engaged in bibliographical endeavour to preserve their correspondence. Not only is this for the benefit, in my case, of future local historians, but also for the use of other specialists such as bibliographers, social historians, biographers, genealogists, and perhaps other research 
fields not yet dreamed of. The present great interest in Canadian studies, and the concomitant gathering of manuscript and printed collections, means that there should be no difficulty in finding a satisfactory depository for your materials. If your mind is not made up however, I would like to notice here that the Archivist of my own institution, Queen's University, is establishing a centre for the preservation and use of bibliographical papers, and is actively seeking further deposits. We already have the collections of several illustrious Canadian bibliographers, including those of Dr. R.E. Watters and of our Chairman, Dr. Bishop, and soon to be added are the records of the Bibliographical Society of Canada itself. You are invited to join this distinguished company by contributing your papers too.

So far this talk has been more didactic than confessional, and I should like to mend this pomposity. Dr. Johnson described a lexicographer as a 'harmless drudge'; should bibliographers be any less modest? Harmless no doubt we are, and some drudgery we may encounter; but for the most part bibliography is an immensely absorbing pursuit that rewards us with endless fascination and entertainment. Patience and persistence are essential attributes though and the serious practitioner, recognizing that a job well done will not soon have to be done again, will try to heed the scriptural advice "Whatsoever they hand findeth to do, do it with thy might". For there is allure even in detail. As an example, the very first history of this beautiful city of Montreal was written as early as about 1672, by Dollier de Casson; but the manuscript was set aside, and it did not appear in print till 1868, two hundred years later, by which time it had been beaten to the press by several other histories. ${ }^{2}$ Dollier, by the way, was Superior of Montreal's Sulpician Seminary, the great library of which until recently I believe occupied this very building. Historians of the city of Toronto will certainly know Conygham Crawford Taylor's Toronto "Called Back, " From 1886 to 1850 (Toronto, 1886), but it is not so well known that these title-page dates vary, indicating in fact no less than six distinct editions of this work, from 1886 to 1897.

There are some surprises too. For example, I could find no history of Summerside, the second largest community of Prince Edward Island, which had been published up to 1950, the terminal date of the bibliography. Yet the history of a place called Belfast, a few miles the other side of Charlottetown, a community so small it exists now only in the name of a post office, is enshrined in not one but two local histories. ${ }^{3}$ An even bigger surprise was in being unable to find a single history of Waterloo, Ontario, founded in 1806 and by 1950 a city of about 12,000 people.

Frustrations and failures abound, but they provide valuable experience. I recall following the trail of a reference to what would have been the earliest edition of the history of an old Nova Scotian community. Ultimately I learned that there was a copy, probably the last one in existence, in a remote library in Cape Breton, so I wrote in some jubilation. The reply was most apologetic: after

\footnotetext{
${ }^{2}$ For example, those by Bosworth and Warburton, published in 1839 and 1846 respectively.

${ }^{3}$ MacQueen's Skye Pioneers (Winnipeg, 1929) and Putnam's Selkirk Settlers (Kentville, N.S., 1933).
} 
many years of use this old volume had fallen apart, and just a couple of weeks earlier it had been discarded. A hopeful note was added: Would you like to borrow our copy of the latest edition?

There was a different problem with the reprint of a history of a police village north of Toronto: I had an actual copy of the work all right, but it bore no imprint whatsoever. Letters to local newspapers and libraries eventually revealed the name of the printer, but several letters I sent brought no response. At last, in desperation, I wrote to the local police department, and the Chief kindly contacted the printer, who admitted to receiving my letters and promised a reply soon. Three months later all was still silence, so I sent one final letter to the printer; this too was never answered, and the facts of the reprint are still clouded with uncertainty. Some time later it occurred to me that perhaps this reprint had been published without the copyright holder's permission; with more consideration than he had extended to me, I thereupon removed the printer's name from the bibliographical entry for the reprint.

Two more case-histories which ended in bafflement concern a work on Muskoka and another on Yellowknife, N.W.T. Both histories were reported in issues of the Canadian Catalogue of Books, ${ }^{4}$ published by Toronto Public Library, which work has the advantage of being contemporary with the titles it lists. I was never able to see copies of either but their publication was, to me, so sufficiently likely that I listed them both, with of course proper cautionary notes. The first one, Muskoka, by Olive Knowlton, was published in Bracebridge in 1924. Although I corresponded with libraries and newspapers in the region and elsewhere, as well as local historians and elderly inhabitants, over a two year period, I was never able to locate a single copy, nor find any person who had ever set eyes on one. The file on $A$ Short History of Yellowknife, by John McMeekan (Toronto, 1944) is an even thicker one, though my inquiries were spread over only 12 months. When southern Canadian libraries reported no knowledge of the work I began a wide correspondence in the Yukon and North West Territories, beginning of course with Yellowknife, but everywhere I drew a blank. Then a local historian surprised me with the address of the author's widow. This lady, it transpired, was busy preparing a collection of her husband's writings for the press, and all the replies I ever received from her were filled with questions about publishers, copyright, and legal proceedings to retrieve a quantity of her late husband's papers. It was a correspondence richer in intrigue than in details of the Yellowknife history. At one point an old-timer wrote saying he knew of a Yellowknife basement filled with copies of the history I sought, and that he would send me one if I wished; but perhaps it was an unkind joke, because it came to nought. Neither did the correspondence with the author's widow come to much, for it petered out when she changed her address for the fifth time within a few months, and I lost track of her before ever finding a copy of the history.

One last incident because, in retrospect, it was unique for me. After a long quest for a copy of a certain history of Collingwood, Ontario, I petitioned a local newspaper for help. I offered to write a short local history article for publication if the editor would allow me to include an appeal to borrow a copy of the wanted title. He agreed, and the result was a letter from a lady who assured me that she

${ }^{4}$ Reprinted Toronto, 1959, 2 vols.; the two titles are cited at I:E12 and II:Y23 respectively. 
possessed the title I sought, and that she would be pleased to let me see it - for a fee of $\$ 10.00$ ! I had never had such an offer before, nor since, and was sorely tempted to bend my principles. I declined however, and fortunately another copy was eventually found. Incidentally, this offer to write a short article of local history, incorporating my own inquiries, was accepted by several smalltown newspapers afterwards, and the arrangement was quite often successful.

Disappointments were always greatly outnumbered by encouragements, not the least of which was the unfailing help of the National Library in arranging loans, and especially of the Canadian Union Catalogue in furnishing not only thousands of locations, but also unexpected notes on other editions or variant titles which, but for this courtesy, might well have gone unnoticed. Yet another pleasure was in finding what a splendid collection of Canadian local histories is held in the library of the Public Archives of Canada - and what a wonderfully helpful staff has the care of them.

I have indicated the number of volumes a bibliographer is likely to handle, some of the methods he might use to obtain information about them, the mass of correspondence this produces, and related some of my own experiences. Many more 'confessions' could be dredged from the depths of my files, and the shallows of my fading memory, but fortunately for you the time is already gone.

As the years roll by, and your bibliography advances at glacial speed, a certain question begins to enter into conversations with friends: When do you think you'll be finished? Well, they might as well ask how far it is to the Celestial City. Columbus must have been asked a similar question by the crew of the Santa Maria: How far is it to Cathay now, my Captain? When you are travelling in strange waters without benefit of charts, you can have only the vaguest idea of the length of the voyage. In a sense a bibliography is a chart, compiled by the explorer, for it defines the voyage and circumscribes the area. Time may show the need for corrections, and an enlargement of grid; but henceforth travellers in the region have a datum against which to measure direction and scale. Before a bibliography is attempted, the proportions and even the nature of its subject can only be a matter for speculation. Moreover, for books to be used, their existence must first be known. For the bibliographer, no less than the cartographer of new lands, definitiveness can only have meaning in relation to a state of development towards ultimate Truth.

At last you reach port, and you have described the final title. You may think you are finished, but there are still many things to do: the introduction to write, the illustrations to select with permissions to copy gained, tables of contents, illustrations, abbreviations, sources, and so forth, to compile, and the daunting task of compiling the index to face (this should never be delegated entirely for it is the author's own subject, and the systematic analysis required by indexing also provides one last opportunity for making corrections to the text). Meantime, you must be considering the most important matter of publication. The manuscript, smelling strongly of midnight oil and (if you are a librarian) compiled mostly by the light of a candle burning at both ends, is sent to a publisher. Those blessed by good fortune will receive a memorandum of agreement, a fairly standard document which begins: 
The Author hereby grants and assigns to the Publisher the sole and exclusive world rights to copyright, produce, and publish in book and microfiche form...

and so forth, and then follows the title of your book; or what you had thought was your book. Later on there's another chilling passage which reads

Should it . . . in the opinion of the Publisher, become necessary to offer a revised edition of the said work the Author agrees to prepare at his own expense the manuscript of such revision...., and should the Author... be unable or unwilling to prepare such a revision then ...

Well, in short, the publisher can have the editing done and the costs charged against your future royalties. You may feel your gorge rising. What rights is the author permitted to keep, you may ask, in return for his years of patient labour? Well, bear in mind firstly that the agreement form is so standard that it even claims for the publisher fifty per cent of the serial, broadcasting, and movie rights for your bibliography. Next, it is well to remind yourself at this crucial point that bibliography is in the same category as virtue, it being its own reward. However, and this is my last observation, there is a way in which your bibliographical knowledge may be turned to your material benefit. And I'm not forgetting that every Thomas J. Wise has his Carter and Pollard! No, this is legal, and fun. I suggest that if possible you combine your bibliographical researches with book-collecting in the same subject field, for the interaction will enlarge your interest and pleasure in both. You will know the most important works and the best editions in your field, and perhaps some titles which even booksellers do not realize belong to your subject at all. Your years of learning, and the rising values of Canadiana, will provide a handy nest-egg for your retirement. If you are interested in extracting a pecuniary advantage from your bibliographical labours, don't let this opportunity slip by; it may be the only one you have.

WILLIAM F.E. MORLEY 